\title{
Pelatihan Teknologi Bio-induksi untuk Petani Gaharu di Desa Pejaring, Kabupaten Lombok Timur
}

\section{(Training of Bio-induction Technology on Agarwood Farmers of Pejaring Village, Lombok Timur District)}

\author{
I Gde Adi Suryawan Wangiyana ${ }^{*}$, Sad Kurniati Wanitaningsih'1, Lutfi Anggadhania ${ }^{2}$ \\ ${ }^{1}$ Program Studi Kehutanan, Fakultas Sains Teknik Terapan, Universitas Pendidikan Mandalika \\ Jl. Pemuda No 59A Dasan Agung, Kota Mataram. \\ 2 Balai Penelitian Teknologi Hasil Hutan Bukan Kayu, Jl. Dharma Bhakti No. 7 Lingsar, Kabupaten Lombok Barat. \\ *Penulis Korespondensi: dede.consultant@gmail.com \\ Diterima Mei 2019/Disetujui September 2019
}

\begin{abstract}
ABSTRAK
Petani gaharu di Desa Pejaring masih menggunakan metode tradisional dalam menginduksi resin gaharu. Tujuan dari kegiatan pengabdian kepada masyarakat ini adalah untuk melakukan pelatihan aplikasi teknologi bio-induksi sebagai pengganti metode tradisional bagi petani gaharu di Desa Pejaring. Petani gaharu di Desa Pejaring terlibat langsung dalam setiap tahap kegiatan bio-induksi. Kegiatan tersebut dimulai dari tahap sosialisasi kegiatan melalui Focus Group Discussion (FGD) sekaligus pemberian teori bio-induksi. Tahap penerapan teori dimulai dari kegiatan seleksi pohon gaharu di kebun untuk dijadikan sampel. Selanjutnya adalah kegiatan bio-induksi pada pohon gaharu sampel dengan metode bor dan suntik. Tahap akhir, petani gaharu diajarkan untuk melakukan monitoring dan evaluasi resin pada pohon gaharu sampel sebagai produk bio-induksi. Pada tahap ini, petani gaharu juga diberi kesempatan untuk melakukan penilaian kualitas resin tersebut secara organoleptik. Petani gaharu di Desa Pejaring mampu menguasai teknologi bio-induksi pada pohon gaharu sampel. Metode bio-induksi tersebut mampu menstimulasi pembentukan resin pada pohon gaharu sampel tiga bulan pascapenyuntikan. Hal ini merupakan kemajuan yang signifikan dibandingkan dengan metode tradisional yang selama ini dilakukan oleh petani gaharu. Hasil pengamatan secara organoleptik oleh petani gaharu di Desa Pejaring juga menunjukkan hasil bio-induksi yang mereka lakukan memiliki tingkat keharuman cukup memuaskan. Sebagai tambahan, meskipun hasilnya tidak sebaik ketika didampingi, petani gaharu Desa Pejaring tetap dapat melakukan bio-induksi secara mandiri menggunakan inokulan dari Balai Penelitian Teknologi Hasil Hutan Bukan Kayu (BPTHHBK) dan diperbanyak dengan metode sederhana. Petani gaharu Desa Pejaring telah memahami dan mampu mengaplikasikan teknologi bio-induksi sebagai pengganti metode tradisional yang selama ini mereka gunakan.
\end{abstract}

Kata kunci: bio-induksi, Desa Pejaring, petani gaharu

\begin{abstract}
Agar wood farmer of Pejaring Village have used traditional method to induce resin formation on agarwood tree. They used mechanical method induction by nail and machete tools as well as chemical method induction by chemical liquid that the called by "infus". These traditional methods influenced resin formation on agarwood tree at their agarwood plantation. That resin production was low in productivity and low in efficiency. The purpose of this community service was to conducted workshop of bio-induction technology for Pejaring Village agarwood farmer to solve their problem. Agarwood farmer of Pejaring Village were directly involved in all bioinduction training activity. This training was started by socialization of program through FGD with Agarwood Farmer of Pejaring Villange. Practical stage was started by selecting agarwood tree for sample by themselves. After selecting process has been done, training continued by bio-induction of agarwood sample using bore and injecting method also by themselves. The last stage was monitoring and evaluating of resin production on agarwood sample as result of bio-induction. In this stage, they got opportunity to give self-assessment of those resin production by organoleptic test. Bio-induction technology could stimulate resin formation on agarwood tree sample at 3 months after induction. This result was much better comparing to the result of traditional induction method that they used to conducted. Organoleptic test has confirmed that resin has quite good fragrance quality. It could be concluded that Pejaring Village agarwood farmers have understood about bioinduction technique and could applied that technology to replace traditional technology.
\end{abstract}

Keywords: agarwood farmer, bio-induction, Pejaring Village 


\section{PENDAHULUAN}

Gaharu merupakan komoditas hasil hutan bukan kayu yang memiliki nilai ekonomis tinggi. Spesies tanaman penghasil gaharu tersebar hampir diseluruh provinsi di wilayah Indonesia (Turjaman \& Hidayat 2017). Gyrinops versteegii merupakan salah satu tanaman gaharu endemik dari kepulauan Nusa Tenggara, termasuk Pulau Lombok (Mulyaningsih \& Yamada 2008). Spesies ini banyak tumbuh secara alami di wilayah Lombok Utara khususnya hutan Senaru (Wangiyana \& Sukardi 2018). Eksploitasi besarbesaran terhadap spesies ini menyebabkan spesies gaharu alam termasuk $G$. versteegii masuk dalam daftar CIETES apendix II (Schmidt 2011). Artinya terdapat pembatasan eksploitasi terhadap spesies alam dari komoditas ini. Padahal gaharu merupakan salah satu komoditas hasil hutan bukan kayu bernilai ekonomis tinggi yang potensial dimanfaatkan untuk menyejahterakan penduduk Nusa Tenggara Barat umumnya dan Pulau Lombok Khususnya (Siddik 2010)

Salah satu solusi agar komoditas gaharu tetap dapat berkelanjutan tanpa mengorbankan spesies alam adalah melalui budi daya. Spesies penghasil gaharu memiliki aroma harum karena memproduksi resin yang didominasi oleh senyawa sesquiterpen, chromones, aromatic, dan triterpen (Nasution et al. 2019). Resin tersebut merupakan salah satu respons spesies gaharu terhadap adanya gangguan baik secara fisik, kimia ataupun biologis yang dikenal dengan istilah induksi (Sundaram \& Khapugin 2017). Produksi resin tersebut pada spesies gaharu alam membutuhkan waktu relatif lama. Terlebih lagi, tidak semua gaharu spesies alam menghasilkan resin tersebut karena resin tersebut hanya dihasilkan oleh pohon gaharu telah terinduksi (Akter et al. 2013). Hal inilah yang menyebabkan pemnfaatan komoditas gaharu spesies alam menjadi tidak efisien jika dibandingkan dengan gaharu budi daya. Meskipun secara kualitas gaharu alam umumnya jauh lebih unggul dibandingkan gaharu budi daya.

Petani gaharu di Desa Pejaring merupakan salah satu pelaku budi daya gaharu di wilayah Pulau Lombok, khususnya di wilayah Lombok Timur. Mereka telah mulai menanam pohon gaharu sejak awal tahun 2000, namun saat ini mereka belum memeroleh hasil optimal dari pohon gaharu (G. versteegii) yang ditanam. Permasalahan tersebut terkait rendahnya produktivitas resin pohon gaharu karena kurang optimal melakukan induksi. Induksi yang selama ini dilakukan oleh petani gaharu Pejaring Timur adalah metode induksi secara tradisional. Induksi yang dilakukan antara lain secara mekanik dengan menggunakan golok dan paku. Selain itu, petani juga menggunakan metode kimiawi menggunakan cairan yang disebut "infus" dengan komposisi yang belum teruji secara ilmiah. Solusi untuk permasalahan ini adalah menerapkan metode induksi yang lebih optimal, yaitu melalui metode bio-induksi.

Metode bio-induksi adalah metode yang dikembangkan oleh tim $R \& D$ Centre for Forest Conservation and Rehabilitation dengan prinsip menyuntikkan jamur pathogen (inokulan) ke dalam batang pohon gaharu untuk menstimulasi pembentukan resin. Resin dihasilkan oleh pohon gaharu sebagai bentuk pertahanan diri terhadap inokulan. Metode bio-induksi telah mengalami perkembangan dari sebelumnya menggunakan inokulan padat dengan tingkat keberhasilan pembentukan resin 40-60\% sampai menggunakan inokulan cair dengan tingkat keberhasilan pembentukan resin $90-100 \%$ (Santoso \& Turjaman 2011). Sementara itu, jamur pathogen sebagai inokulan yang teruji efektif menginduksi pembentukan resin gaharu adalah kelompok Fusarium (Santoso et al. 2011). Metode bioinduksi dengan inokulan Fusarium merupakan solusi yang tepat dari permasalahan petani gaharu di Desa Pejaring.

Bio-induksi merupakan teknologi yang sudah teruji secara ilmiah mampu mengoptimalkan produksi resin pada pohon gaharu (Turjaman et al. 2016; Nasution et al. 2019). Meskipun demikian, teknologi ini merupakan teknologi yang masih belum dipahami dengan baik oleh masyarakat petani di Desa Pejaring. Teknologi ini merupakan sesuatu yang masih awam, sehingga petani gaharu tidak langsung percaya bahwa teknologi ini merupakan solusi dari permasalahan mereka. Tim peneliti dari Fakultas Ilmu Kehutanan, Universitas Nusa Tenggara Barat telah melakukan penelitian pendahuluan terkait aplikasi metode ini dan menghasilkan temuan produksi resin gaharu yang menjanjikan (Wangiyana et al. 2018). Hasil dari penelitian ini mampu menarik minat petani gaharu di Desa Pejaring untuk menerapkan metode bio-induksi sebagai solusi dari permasalahan mereka.

Minat petani gaharu di Desa Pejaring untuk meningkatkan produktivitas resin gaharu melalui teknologi bio-induksi harus diimbangi dengan kemampuan dalam mengaplikasikan teknologi tersebut. Kegiatan pelatihan diperlukan untuk membantu petani gaharu memahami 
secara menyeluruh teknologi bioinduksi karena merupakan sesuatu yang baru. Oleh karena itu, kegiatan pengabdian kepada masyarakat ini bertujuan untuk melatih petani gaharu di Desa Pejaring mengaplikasikan teknologi bio-induksi sebagai pengganti metode tradisional sehingga mampu meningkatkan efektivitas produksi resin di kebun gaharu mereka.

\section{METODE PELAKSANAAN KEGIATAN}

Kegiatan Pengabdian kepada masyarakat dilaksanakan di Dusun Pejaring Timur, Desa Pejaring, Kecamatan Sakra, Kabupaten Lombok Timur, Provinsi Nusa Tenggara Barat. Masyarakat yang menjadi partisipan kegiatan pengabdian kepada masyarakat ini adalah petani gaharu di Desa Pejaring. Jumlah Partisipan yang terlibat sebanyak 9 orang petani gaharu yang memiliki pohon gaharu dilahan mereka serta memiliki keinginan yang kuat untuk mempelajari metode bio-induksi. Selain itu, pertimbangan pemilihan partisipan adalah rentang usia yang produktif berkisar antara 20-50 tahun. Masingmasing partisipan dalam kegiatan pelatihan berkontribusi untuk menyediakan paling sedikit 2 pohon gaharu yang layak untuk dijadikan sampel kegiatan bio-induksi. Pohon tersebut rata-rata telah mencapai usia lebih dari 10 tahun dengan kisaran diameter batang antara 10-25 $\mathrm{cm}$.

Masyarakat petani gaharu Desa Pejaring terlibat secara aktif dalam setiap kegiatan yang dilakukan. Mereka terlibat mulai dari tahap persiapan kegiatan bio-induksi sampai pada tahap monitoring dan evaluasi hasil bio-induksi. Tahapan kegiatan pengabdian kepada masyarkat ini secara umum disajikan pada Gambar 1.

\section{Bahan dan Alat}

Alat yang digunakan dalam kegiatan ini antara lain: seperangkat bor listrik dengan mata bor diameter 3-5 mm dan blender food grade. Bahan yang digunakan antara lain: isolat Fusarium Sp. dari Balai Penelitian Teknologi Hasil Hutan Bukan Kayu, di Kecamatan Lingsar, Kabupaten Lombok Barat, alkohol 70\%, spuit injector volume $10 \mathrm{~mL}$, lem silicon, cutter, cawan petri diameter 9 $\mathrm{cm}$ dan botol plastik nomor 2 (dari bahan HDPE).

\section{Sosialisasi Kegiatan}

Sosalisasi kegiatan dilakukan melalui Focus Group Discussion (FGD). Pada kegiatan ini petani gaharu di Desa Pejaring selaku partisipan diberi pembekalan materi terkait metode Bio-induksi. Beberapa point pokok yang dibahas dalam FGD adalah 1) Pemilihan pohon gaharu yang ideal sebagai sampel untuk kegiatan bio-induksi; 2) Alat dan bahan serta persiapan yang perlu dilakukan sebelum melakukan Bio-induksi; 3) Pembekalan teori pelaksanaan kegiatan bioinduksi secara teknis; dan 4) Pembekalan teknik evaluasi hasil bio-induksi pada pohon gaharu.

\section{Persiapan Bio-induksi}

Sebelum melakukan bio-induksi yang harus dilakukan adalah memilih pohon gaharu yang akan dijadikan sampel. Seleksi dilakukan dengan memilih pohon gaharu yang memiliki kondisi sehat serta bebas dari hama penyakit. Selain itu, pohon gaharu yang ideal untuk dijadikan sampel metode bio-induksi adalah yang memiliki diameter batang 15-20 cm (Iskandar \& Suhendra 2012). Pada lahan partisipan terdapat beberapa pohon gaharu yang memiliki diameter $10-14 \mathrm{~cm}$, pohon tersebut tetap digunakan sebagai sampel karena secara fisik kondisinya sehat serta bebas hama penyakit. Selain itu, pohon gaharu tersebut dapat digunakan sebagai pembanding dengan pohon gaharu ideal (diameter $15-20 \mathrm{~cm}$ ) yang juga dijadikan sampel untuk bio-induksi.

Setelah sampel pohon gaharu yang akan dibioinduksi ditentukan, langkah selanjutnya adalah mempersiapkan bahan yang akan digunakan untuk kegiatan bio-induksi. Bahan utama dalam kegiatan bio-induksi adalah isolat Fusarium sp. dari Balai Penelitian Teknologi Hasil Hutan Bukan Kayu (Yosephin et al. 2012). Tim pengabdian kepada masyarakat melakukan peremajaan terlebih dahulu terhadap isolat Fusarium sp. pada medium potato dextrose agar

\begin{tabular}{|l|l|}
\hline 1 & -Pre-test awal sebelum kegiatan pelatihan \\
\hline 2 & -Pembekalan teori melalui FGD \\
\hline 4 & -Seleksi pohon gaharu sampel \\
\hline 5 & $\begin{array}{l}\text {-Pelatihan bio-induksi bersama petani } \\
\text { gaharu }\end{array}$ \\
\hline 6 & -Post-test pasca kegiatan pelatihan \\
\hline 7 & - Monitoring dan evaluasi \\
\hline
\end{tabular}

Gambar 1 Tahapan umum kegiatan bio-induksi di Desa Pejaring. 
(Difco). Selanjutnya, petani gaharu diberi kesempatan untuk memindahkan isolat pada medium agar ke medium cair. Medium cair yang digunakan adalah medium Tauge Broth yang mengandung ekstrak tauge sebanyak 20\% dan dekstrosa sebanyak 15\% (Wangiyana 2015). Pemindahan dilakukan dalam Enkas sebagai pengganti Laminar Air Flow untuk menyediakan tempat kultur yang aseptis. Pemindahan dilakukan dengan membagi 3 miselium isolat pada medium agar dalam cawan petri diameter $9 \mathrm{~cm}$ dengan menggunakan cutter. Selanjutnya setiap potongan dimasukkan dalam medium cair dalam botol plastik nomor 3 (HPDE) volume $500 \mathrm{~mL}$. Setelah satu bulan inokulan siap digunakan untuk kegiatan bio-induksi.

\section{Pelatihan Metode Bio-induksi}

Kegiatan utama dalam bio-induksi adalah menyuntikkan inokulan cair ke dalam batang pohon gaharu sampel. Tahap ini juga merupakan bagian paling penting dalam kegiatan bioinduksi karena menentukan keberhasilan pembentukan resin gaharu. Oleh karena itu, tim pengabdian kepada masyarakat memberikan pelatihan secara intensif terkait kegiatan ini kepada petani gaharu.

Partisipan yang terlibat dalam kegiatan pelatihan adalah 9 orang petani gaharu yang sudah berkontribusi menyumbangkan dua pohon gaharu untuk dijadikan sampel. Partisipan diberikan modul sederhana terkait materi bioinduksi sebagai pedoman di lapangan. Sebelum terjun kelapangan melakukan bio-induksi, partisipan diminta mengisi kuesioner dalam modul untuk menguji tingkat pemahaman mereka. Selanjutnya, partisipan terlibat secara langsung melakukan bio-induksi pada sampel pohon gaharu yang telah diseleksi. Dengan demikian, diharapkan kedepannya petani gaharu mampu secara mandiri melakukan bio-induksi tanpa didampingi oleh tim pengabdian.

Dalam pelatihan ditekankan bahwa langkahlangkah yang dilakukan dalam metode bioinduksi harus sitematis. Langkah pertama adalah menghaluskan inokulan cair dengan menggunakan blender. Langkah Kedua melakukan pengeboran pada batang gaharu sampel dengan menggunakan mata bor diameter $3 \mathrm{~mm}$. Kedalaman pengeboran adalah 4-7 $\mathrm{cm}$ tergantung diameter batang. Pengeboran dilakukan dengan teknik injeksi spiral, yaitu jarak antar-lubang bor adalah $10 \mathrm{~cm}$ secara horizontal dan $10 \mathrm{~cm}$ secara vertikal. Pengeboran juga dilakukan tidak tegak lurus terhadap permukaan batang, melainkan membentuk sudut sekitar $45^{\circ}$. Tahap ketiga adalah menyuntikan sebanyak $2 \mathrm{~mL}$ inokulan cair yang sudah dihaluskan dengan blender ke dalam lubang bor menggunakan spuit injeksi. Langkah terakhir adalah menutup lubang inokulasi dengan menggunakan lem silicon (Wangiyana et al. 2018).

\section{Monitoring dan Evaluasi Kegiatan}

Tahap monitoring dan evaluasi bertujuan untuk mengamati tingkat keberhasilan metode bio-induksi dalam menstimulasi pembentukan resin pada batang gaharu. Monitoring dilakukan setiap bulan pascaproses bio-induksi selama 3 bulan. Perubahan warna kulit batang gaharu di sekitar areal inokulasi menjadi cokelat kehitaman merupakan parameter utama pembentukan resin gaharu. Hal ini merupakan suatu hal esensial untuk dipahami oleh petani gaharu di Desa Pejaring ketika kelak mereka mampu melakukan bio-induksi secara mandiri. Batang pohon gaharu pada areal inokulasi yang telah membentuk resin gaharu selanjutnya disayat secara tangensial menggunakan cutter. Potongan batang tersebut selanjutnya digunakan sebagai sampel untuk uji organoleptik.

\section{Uji Organoleptik}

Uji organoleptik dilakukan untuk menguji tingkat keharuman sayatan sampel batang pohon gaharu yang telah menghasilkan resin. Uji organoleptik dilakukan dengan membakar sayatan sampel batang kemudian diberikan pada responden untuk dinilai tingkat keharumannya. Responden memberikan penilaian tingkat keharuman skala 1-5 dengan ketentuan: $1=$ tidak harum, 2 = sedikit harum, 3 = harum, $4=$ sangat harum, dan 5 = sangat harum sekali.

\section{HASIL DAN PEMBAHASAN}

\section{Sosialisasi Kegiatan melalui FGD}

Pada sosialisasi kegiatan melalui FGD, tim pengabdi menggali lebih dalam kendala yang dialami oleh petani gaharu di Desa Pejaring dalam melakukan budi daya gaharu. Kendala tersebut adalah belum optimalnya produksi resin yang dihasilkan dari pohon gaharu yang mereka budidayakan. Belum optimalnya produksi tersebut disebabkan petani gaharu belum memahami pentingnya melakukan induksi pada pohon gaharu agar mampu menghasilkan resin. 
Pada kegiatan FGD ini petani gaharu diajarkan teknik dasar dalam melakukan kegiatan bioinduksi mulai dari persiapan sampai pada monitoring dan evaluasi kegiatan. Secara teoritis, lebih dari $70 \%$ petani gaharu yang mengikuti kegiatan FGD dapat dengan mudah memahami teknologi bio-induksi. Hal ini dikarenakan, sebagian besar berprofesi sebagai tukang kayu sehingga tidak asing dengan kegiatan pengeboran kayu yang menjadi kegiatan utama dalam bio-induksi. Berdasarkan hasil FGD, dapat disimpulkan bahwa petani gaharu di Desa Pejaring siap untuk melakukan bio-induksi pada pohon gaharu di lahan mereka. Gambar 2 menunjukkan bahwa sosialisasi teknologi bioinduksi di kebun milik petani gaharu di Desa Pejaring.

\section{Persiapan Kegiatan Bio-induksi}

Petani gaharu di Desa Pejaring memiliki banyak pohon gaharu di kebun mereka, namun tidak semua layak untuk dijadikan sampel kegiatan bio-induksi. Pohon gaharu yang dijadikan sampel harus memiliki diameter minimal $10 \mathrm{~cm}$ agar layak untuk di jadikan sampel bio-induksi. Berdasarkan hal tersebut, tim pengabdi dan petani gaharu telah memilih sebanyak 16 pohon gaharu yang layak untuk dijadikan sampel. Pohon hasil seleksi tersebut selanjutnya diberi kode untuk proses bioinduksi (Tabel 1).

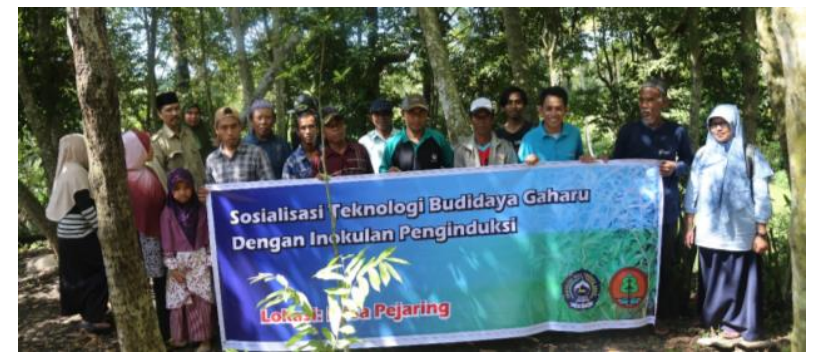

Gambar 2 Sosialisasi teknologi bio-induksi di kebun milik petani gaharu di Desa Pejaring.

Tabel 1 Hasil seleksi pohon gaharu sampel bersama petani gaharu

\begin{tabular}{|c|c|c|c|}
\hline $\begin{array}{c}\text { Kode } \\
\text { pohon }\end{array}$ & $\begin{array}{l}\text { Lingkar } \\
\text { pohon }(\mathrm{cm})\end{array}$ & $\begin{array}{l}\text { Diameter } \\
(\mathrm{cm})\end{array}$ & Rekomendasi \\
\hline 1 & 71 & 23 & $\begin{array}{l}\text { Kondisi pohon sehat dan layak untuk disuntik. Kedalaman pengeboran } \\
\text { sekitar } 7 \mathrm{~cm}\end{array}$ \\
\hline 2 & 58 & 18 & $\begin{array}{l}\text { Kondisi pohon sehat, dan layak untuk disuntik. Kedalaman } \\
\text { pengeboran sekitar } 6 \mathrm{~cm}\end{array}$ \\
\hline 3 & 65 & 21 & $\begin{array}{l}\text { Kondisi pohon sehat, dan layak untuk disuntik Kedalaman pengeboran } \\
\text { sekitar } 6 \mathrm{~cm}\end{array}$ \\
\hline 4 & 78 & 25 & $\begin{array}{l}\text { Kondisi pohon sehat dan layak untuk disuntik. Kedalaman pengeboran } \\
\text { sekitar } 8 \mathrm{~cm}\end{array}$ \\
\hline 5 & 71 & 23 & $\begin{array}{l}\text { Kondisi pohon sehat dan layak untuk disuntik. Kedalaman pengeboran } \\
\text { sekitar } 7 \mathrm{~cm}\end{array}$ \\
\hline 6 & 67 & 21 & $\begin{array}{l}\text { Kondisi pohon sehat dan layak untuk disuntik. Kedalaman pengeboran } \\
\text { sekitar } 7 \mathrm{~cm}\end{array}$ \\
\hline 7 & 50 & 16 & $\begin{array}{l}\text { Kondisi pohon sehat dan layak untuk disuntik. Kedalaman pengeboran } \\
\text { sekitar } 5 \mathrm{~cm}\end{array}$ \\
\hline 8 & 50 & 16 & $\begin{array}{l}\text { Kondisi pohon sehat dan layak untuk disuntik. Kedalaman pengeboran } \\
\text { sekitar } 5 \mathrm{~cm}\end{array}$ \\
\hline 9 & 60 & 19 & $\begin{array}{l}\text { Kondisi pohon sehat dan layak untuk disuntik. Kedalaman pengeboran } \\
\text { sekitar } 5 \mathrm{~cm}\end{array}$ \\
\hline 10 & 36 & 11 & $\begin{array}{l}\text { Kondisi pohon sehat dan cukup layak untuk suntik. Kedalaman } \\
\text { pengeboran sekitar } 3,5 \mathrm{~cm}\end{array}$ \\
\hline 11 & 43 & 14 & $\begin{array}{l}\text { Kondisi pohon sehat dan cukup layak untuk suntik. Kedalaman } \\
\text { pengeboran sekitar } 4,5 \mathrm{~cm}\end{array}$ \\
\hline 12 & 39 & 12 & $\begin{array}{l}\text { Kondisi pohon sehat dan cukup layak untuk suntik. Kedalaman } \\
\text { pengeboran sekitar } 4 \mathrm{~cm}\end{array}$ \\
\hline 14 & 30 & 10 & $\begin{array}{l}\text { Kondisi pohon sehat dan cukup layak untuk suntik. Kedalaman } \\
\text { pengeboran sekitar } 3 \mathrm{~cm}\end{array}$ \\
\hline 15 & 33 & 11 & $\begin{array}{l}\text { Kondisi pohon sehat dan cukup layak untuk suntik. Kedalaman } \\
\text { pengeboran sekitar } 3 \mathrm{~cm}\end{array}$ \\
\hline 16 & 30 & 10 & $\begin{array}{l}\text { Kondisi pohon sehat dan cukup layak untuk suntik. Kedalaman } \\
\text { pengeboran sekitar } 3 \mathrm{~cm}\end{array}$ \\
\hline 17 & 40 & 13 & $\begin{array}{l}\text { Kondisi pohon sehat dan cukup layak untuk suntik. Kedalaman } \\
\text { pengeboran sekitar } 4 \mathrm{~cm}\end{array}$ \\
\hline
\end{tabular}


Seleksi pohon gaharu yang layak untuk dijadikan sampel bio-induksi merupakan suatu hal yang penting untuk dipahami oleh petani gaharu. Seleksi pohon tersebut menentukan tingkat keberhasilan kegiatan bio-induksi menghasilkan resin yang berkualitas. Tim $R \& D$ Centre for Forest Conservation and Rehabilitation sebagai pengembang metode bio-induksi merekomendasikan bahwa kedalaman pengeboran yang ideal adalah $1 / 3$ dari diameter batang (Santoso \& Turjaman 2011). Jika diameter pohon terlalu kecil akan sangat riskan untuk dibor karena berpotensi menimbulkan pengeboran terlalu dalam. Jika Pengeboran terlalu dalam, maka pohon gaharu akan langsung mati karena terganggunya transportasi air. Oleh karena itu, kegiatan seleksi pohon ini menjadi sangat penting.

Petani gaharu di Desa Pejaring dilatih untuk membuat inokulan cair yang akan digunakan dalam kegiatan bio-induksi. Petani gaharu hanya dilibatkan dalam kegiatan pemindahan kultur pada media agar ke media cair karena kegiatan tersebut relatif sederhana, hampir semua petani gaharu yang terlibat mampu melakukannya dengan baik (Gambar 3).

Kegiatan pemindahan kultur ini bersifat opsional bagi petani gaharu di Desa Pejaring karena mereka bisa mendapatkan inokulan cair instan untuk langsung digunakan dalam bioinduksi. Inokulan cair instan umumnya masih cukup langka dan harganya relatif mahal, maka tim pengabdi berinisiatif untuk mengajarkan cara membuatnya. Inokulan cair ini dibuat dari bahan medium alternatif sehingga harganya relatif terjangkau (Wangiyana 2015).

\section{Pelatihan Metode Bio-induksi}

Pelatihan diberikan oleh narasumber dari tim peneliti gaharu dari Fakultas Ilmu Kehutanaan, Universitas Nusa Tenggara Barat dan tim peneliti gaharu dari Balai Penelitian Teknologi Hasil Hutan Bukan Kayu. Kegiatan ini merupakan kegiatan inti dalam proses bio-induksi. Pada kegiatan ini, petani gaharu Desa Pejaring dilatih untuk melakukan bio-induksi sesuai dengan prosedur yang baku. Supaya mudah dipahami oleh petani gaharu, tim pengabdi telah membuat Standar Operasional Prosedur (SOP) setiap tahapan kegiatan bio-induksi agar mereka dapat melakukannya secara sistematis (seperti pada Tabel 2). SOP tersebut sangat memudahkan petani gaharu untuk mengingat tahapan proses dalam bio-induksi.

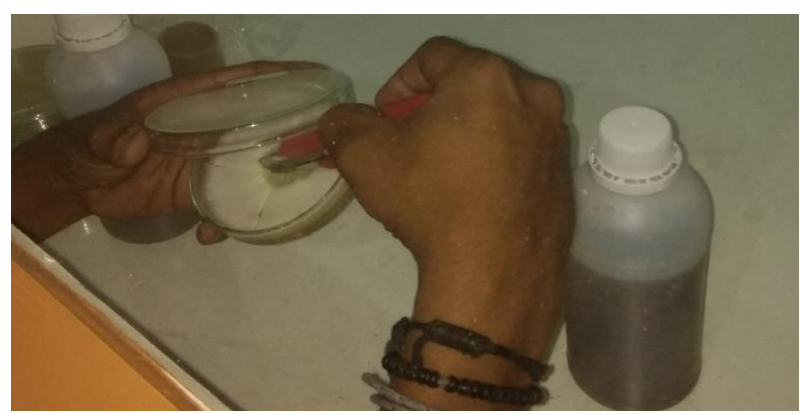

Gambar 3 Proses pemindahan kultur Fusarium sp. padat ke medium cair.

Tabel 2 Standar operasional prosedur (SOP) tahapan proses bio-induksi secara sistematis

\begin{tabular}{|c|c|c|c|}
\hline SOP & Proses & Gambar & Keterangan \\
\hline Tahap 1 & Blending & & $\begin{array}{l}\text { Proses menghaluskan miselium inokulan cair menggunakan } \\
\text { blender selama } 20-30 \text { detik. Tujuannya agar miselium tidak } \\
\text { menyumbat spuit injeksi ketika disuntikkan kedalam lubang } \\
\text { pengeboran. }\end{array}$ \\
\hline Tahap 2 & Boring & & $\begin{array}{l}\text { Proses melubangi batang pohon gaharu sampel dengan } \\
\text { menggunakan mata bor diameter } 3 \mathrm{~mm} \text {. Pengeboran dilakukan } \\
\text { tidak tegak lurus permukaan batang, melainkan membentuk } \\
\text { sudut } \pm 45^{\circ} \text { agar inokulan cair tidak tumpah keluar lubang bor } \\
\text { saat disuntikkan. }\end{array}$ \\
\hline Tahap 3 & Injecting & & 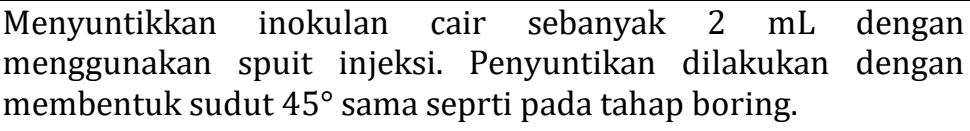 \\
\hline Tahap 4 & Closing & & $\begin{array}{l}\text { Menutup lubang pengeboran dengan lem silicon agar tidak } \\
\text { kemasukan air hujan ataupun kontaminan. }\end{array}$ \\
\hline
\end{tabular}




\section{Monitoring dan Evaluasi}

Tahap ini bertujuan untuk meninjau keberhasilan proses bio-induksi dalam menghasilkan resin pada batang pohon gaharu sampel. Pengamatan dilakukan setiap bulan pasca kegiatan bio-induksi, namun hasil baru terlihat pada 3 bulan pascabio-induksi. Pohon gaharu sampel menunjukkan gejala produksi resin dengan adanya perubahan warna batang pada aeral penyuntikan. Warna yang dihasilkan adalah cokelat kehitaman. Warna batang sampel gaharu yang dijadikan sampel bio-induksi cenderung berubah semakin gelap seiring dengan waktu (Gambar 4).

Hasil kegiatan bio-induksi ini secara signifikan lebih baik dibandingkan dengan metode tradisional yang selama ini dilakukan oleh petani gaharu Desa Pejaring (Gambar 5). Gejala pembentukkan resin dengan menggunakan metode mekanik, yaitu melukai batang menggunakan paku dan golok memerlukan waktu yang sangat lama. Menurut petani gaharu, butuh waktu bertahun-tahun agar hasil induksi dengan paku dan golok ini dapat dipanen, namun hasil yang

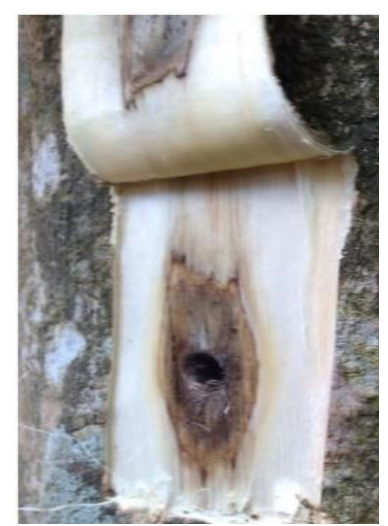

$\mathrm{a}$

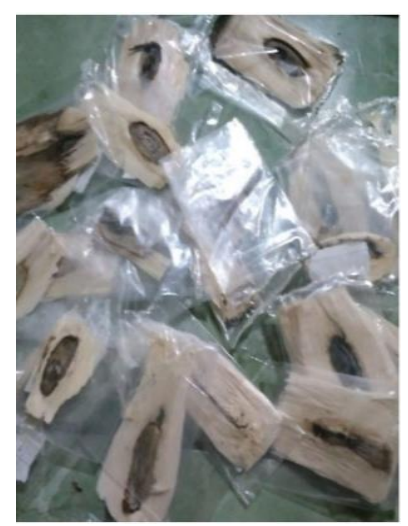

b
Gambar 4 Produksi resin gaharu hasil kegiatan bioinduksi: a) Resin pada pohon gaharu dan b) Resin hasil panen.

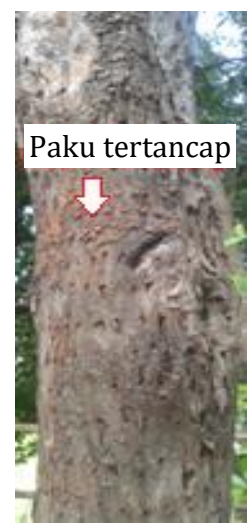

a

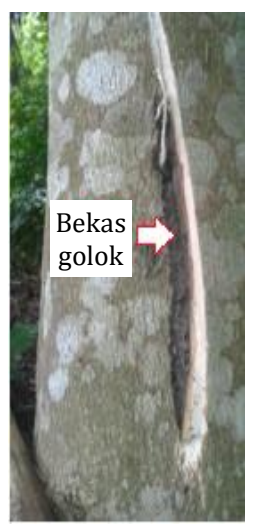

b

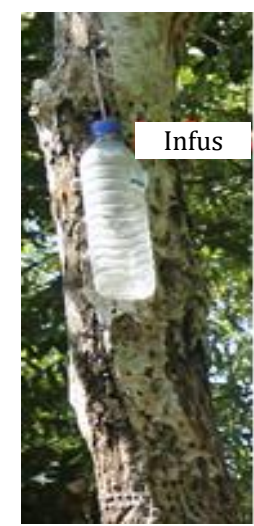

C diperoleh masih jauh dari memuaskan. Induksi menggunakan bahan kimia yang disebut "infus" bahkan memberikan hasil yang lebih parah. Pohon gaharu yang diberi cairan infus menunjukkan gejala melepuh. Jaringan batang menjadi rusak dan tidak menghasilkan dapat resin. Kemungkinan besar bahan yang digunakan adalah bahan kimia keras ataupun reaktif sehingga menimbulkan gejala seperti itu.

Evaluasi kegiatan secara keseluruhan melalui pre-test dan post-test terhadap partisipan juga dilakukan untuk meninjau adanya perubahan pada partisipan setelah melakukan kegiatan. Serangkaian tes tersebut menunjukkan bahwa persentase keberhasilan program adalah cukup memuaskan. Hal ini ditunjukkan dengan adanya perubahan dalam hal pemahaman dan keterampilan partisipan dalam melakukan budi daya gaharu. Selain itu, terdapat peningkatan prolahan kegiatan pengabdian ini. Tabel 3 menunjukkan perubahan yang terjadi pada partisipan setelah kegiatan pengabdian.

Gambar 5 Berbagai metode induksi tradisional: a) Metode induksi paku; b) Metode induksi golok; dan c) Metode induksi infus.

Tabel 3 Perubahan yang terjadi pada partisipan setelah kegiatan pengabdian

\begin{tabular}{|c|c|c|}
\hline \multirow{2}{*}{ Kegiatan yang telah disosialisasikan } & \multicolumn{2}{|c|}{$\begin{array}{c}\text { Tingkat } \\
\text { pemahaman/produktivitas }\end{array}$} \\
\hline & Sebelum (\%) & Sesudah (\%) \\
\hline Pemahaman budi daya gaharu dengan aplikasi metode bio-induksi & 10 & 90 \\
\hline $\begin{array}{l}\text { Keterampilan menginjeksikan inokulan gaharu melalui metode bor dan } \\
\text { suntik sederhana untuk penggunaan mandiri }\end{array}$ & 0 & 60 \\
\hline $\begin{array}{l}\text { Pemahaman melakukan seleksi pohon gaharu yang layak untuk di } \\
\text { induksi }\end{array}$ & 10 & 80 \\
\hline $\begin{array}{l}\text { Pemahaman melakukan monitoring terhadap produksi resin serta uji } \\
\text { organoleptik untuk standarisasi kualitas resin yang dihasilkan }\end{array}$ & 20 & 80 \\
\hline Produktivitas resin gaharu dari kebun partisipan & 10 & 90 \\
\hline Rata-rata & 10 & 80 \\
\hline
\end{tabular}




\section{Hasil Uji Organoleptik}

Uji organoleptik dilakukan untuk menguji tingkat keharuman resin yang dihasilkan oleh pohon gaharu sampel. Berdasarkan penilaian dari responden, terdapat 4 sampel pohon gaharu yang dinyatakan tidak harum, yaitu sampel nomor 1, 2, 4, dan 5. Sampel lainnya, yaitu 12 sampel pohon gaharu dinilai memiliki tingkat keharuman yang bagus mulai dari agak harum sampai harum sekali (Tabel 4). Dapat disimpulkan bahwa keberhasilan proses bio-induksi yang dilakukan oleh petani gaharu di Desa Pejaring mencapai 75\%. Angka ini sudah cukup baik mengingat ini adalah kegiatan bio-induksi yang dilakukan pertama kali. Diharapkan kedepannya petani gaharu mampu meningkatkan keberhasilan produksi resin dengan tingkat keharuman memuaskan, yaitu dengan menambah pengalaman dalam melakukan kegiatan bio-induksi.

Menurut Turjaman et al. (2016), keberhasilan produksi resin beraroma harum melalui bioinduksi ditentukan oleh tiga faktor, yaitu kondisi pohon gaharu, fungi inokulan, dan keadan lingkungan. Faktor kondisi pohon dalam kegiatan pengabdian ini ditinjau dalam hal diameter pohon gaharu yang dijadikan sampel. Rata-rata pohon gaharu di lahan petani gaharu partisipan yang menghasilkan resin beraroma memuaskan memiliki diameter berkisar antara $15-20 \mathrm{~cm}$. Hal

Tabel 4 Hasil uji organoleptik resin pohon gaharu sampel

\begin{tabular}{cccccccccc}
\hline \multirow{2}{*}{ Sampel } & \multicolumn{10}{c}{ Responden } \\
\cline { 2 - 10 } & 1 & 2 & 3 & 4 & 5 & 6 & 7 & 8 & 9 \\
\hline 1 & 1 & 1 & 1 & 1 & 1 & 1 & 1 & 1 & 1 \\
2 & 1 & 1 & 1 & 1 & 1 & 1 & 1 & 1 & 1 \\
3 & 1 & 2 & 1 & 2 & 2 & 2 & 2 & 2 & 1 \\
4 & 1 & 1 & 1 & 1 & 1 & 1 & 1 & 1 & 1 \\
5 & 1 & 1 & 1 & 2 & 1 & 1 & 1 & 1 & 1 \\
6 & 2 & 1 & 2 & 2 & 1 & 2 & 2 & 2 & 2 \\
7 & 2 & 2 & 2 & 2 & 1 & 2 & 2 & 2 & 2 \\
8 & 4 & 3 & 3 & 3 & 2 & 4 & 4 & 3 & 3 \\
9 & 2 & 1 & 2 & 2 & 2 & 2 & 2 & 1 & 2 \\
10 & 3 & 2 & 3 & 3 & 2 & 3 & 3 & 3 & 2 \\
11 & 2 & 2 & 3 & 2 & 2 & 2 & 2 & 2 & 2 \\
12 & 5 & 3 & 3 & 3 & 3 & 3 & 3 & 3 & 2 \\
14 & 2 & 1 & 1 & 2 & 1 & 2 & 2 & 1 & 2 \\
15 & 2 & 2 & 1 & 2 & 1 & 2 & 2 & 2 & 1 \\
16 & 2 & 1 & 2 & 2 & 1 & 1 & 2 & 1 & 1 \\
17 & 1 & 2 & 1 & 1 & 2 & 1 & 2 & 1 & 1 \\
\hline
\end{tabular}

Keterangan: 1 = tidak harum; 2 = sedikit harum; 3 = harum; 4 = sangat harum; dan 5 = sangat harum sekali. ini sekaligus mempertegas bahwa diameter batang 15-20 cm merupakan kriteria pohon gaharu yang ideal untuk dijadikan sampel bioinduksi (Iskandar \& Suhendra 2012).

Berdasarkan kegiatan yang telah dilakukan, petani gaharu di Desa Pejaring diharapkan mampu melakukan kegiatan bio-induksi secara mandiri. Inokulan yang menjadi bahan utama proses bio-induksi dapat diperoleh petani di Balai Penelitian Teknologi Hasil Hutan Bukan Kayu di Wilayah Lingsar, Lombok Barat. Selain itu, tim pengabdian kepada masyarakat juga telah menyisipkan materi pelatihan kepada partisipan untuk memperbanyak inokulan menggunakan medium Tauge Broth (ekstrak tauge 20\% dan dekstrosa 15\%) seperti yang digunakan dalam pelatihan ini. Dengan demikian jika dikemudian hari partisipan memperbanyak penanaman pohon gaharu di lahan mereka, maka tidak akan kesulitan memeroleh inokulan penginduksi dalam jumlah banyak.

\section{SIMPULAN}

Petani gaharu di Desa Pejaring telah memahami metode bio-induksi dengan rata-rata peningkatan pemahaman dan keterampilan sebesar $70 \%$ dibandingkan sebelum adanya kegiatan pelatihan. Petani gaharu juga mampu mengaplikasikan metode bio-induksi pada pohon gaharu, sehingga mampu menstimulasi pembentukan resin secara lebih efisien rata-rata sebesar $80 \%$ dibandingkan dengan metode tradisional yang selama ini dilakukan.

Disarankan agar kegiatan bio-induksi ini berkelanjutan, petani gaharu di Desa Pejaring mendapat bantuan program terkait penjelasan pangsa pasar resin gaharu yang dihasilkan baik lokal, nasional, maupun regional sehinga petani gaharu semakin termotivasi untuk meningkatkan produktivitas resin di kebun gaharu sendiri melalui bio-induksi.

\section{UCAPAN TERIMA KASIH}

Terima kasih diucapkan kepada Direktorat Riset dan Pengabdian Kepada Masyarakat Kementrian Riset, Teknologi dan Pendidikan Tinggi atas dukungan pendanaan untuk kegiatan pengabdian yang menjadi materi utama penulisan artikel publikasi ini. 


\section{DAFTAR PUSTAKA}

Akter S, Islam T, Zulkefeli M, Kahn SI. 2013. Agarwood Production a Multidisciplinary Field to be Explored in Bangladesh. International Journal of Pharmaceutical and Life Science. 1(4): 22-32. https://doi.org/ 10.3329/ijpls.v2i1.15132

Iskandar D, Suhendra A. 2012. Uji Inokulasi Fusarium sp. untuk Produksi Gaharu pada Budi daya $A$. beccariana. Jurnal Sains dan Teknologi Indonesia. 14(3): 182-188. https://doi.org/10.29122/jsti.v14i3.924

Mulyaningsih T, Yamada I. 2008. Notes on Some of Agarwood Species in Nusa Tenggara, Celebes and West Papua. In book: Natural Resource Management and Socio-Economic Transformation under The Decentralization in Indonesia. Kyoto (JP): CSEAS Kyoto University.

Nasution AA, Siregar UJ, Miftahudin, Turjaman M. 2019. Identification of Chemical Compounds in Agarwood-Producing Species Aquilaria malaccensis and Gyrinops versteegii. Journal of Forestry Research.vol dan no. https://doi.org/ 10.1007/s11676-018-00875-9

Santoso E, Turjaman M. 2011. Standardization and Effectiveness of Bioinduction on Gaharu Development and Its Qualities. In: Proceeding of Gaharu Workshop Bioinduction Technology for Sustainable Development and Conservation of Gaharu. Research and Development (R \& D) Centre for Forest Conservation and Rehabilitation, Bogor (ID), 1st July 2011.

Santoso E, Pratiwi, Purnomo E, Irianto RSB, Wiyono B, Novriyanti E, Turjaman M. 2011. Selection Pathogen for Eaglewood (Gaharu) Inoculation. In: Production and Utilization Techonology for Sustainable Development of Eaglewood (Gaharu) in Indonesia Techical Report No. 3. Research and Development (R \& D) Centre for Forest Conservation and Rehabilitation. Bogor

Schmidt MS. 2011. Introduction to CITES and Agarwood Overview. In: Asian Regional Workshop on Agarwood. Indonesia (ID): 2224 November 2011.
Siddik M. 2010. Pengembangan Rantai Nilai Komoditas Gaharu Sebagai Alternatif Pengentasan Kemiskinan di Provinsi Nusa Tenggara Barat. Agroteksos. 20(2-3): 144153.

Sundaram SR, Khapugin AA. 2017. Agarwood: Science Behind the Fragrance. Mohamed $\mathrm{R}$ (editors). New York (US): Springer Publishing.

Turjaman M, Hidayat A, Santoso E. 2016. Development of Agarwood Induction Technology Using Endophytic Fungi. Agarwood, Tropical Forestry. Mohamed R (editors). Singapore (SG): Springer. https://doi.org/10.1007/978-981-10-08337_4

Turjaman M, Hidayat A. 2017. Agarwood-panted Tree Inventory in Indonesia.In: IOP Conference Series: Earh and Environmental Science. https://doi.org/10.1088/1755-1315/54/1/ 012062

Wangiyana IGAS, Malik S. 2018. Application of Arbuscular Mycorrhiza from Senaru Forest Rhizosphere for Gyrinops versteegii Germination and Growth. Biosaintifika: Journal of Biology \& Biology Education. 10(2): 432-438. https://doi.org/10.15294/ biosaintifika.v10i2.14396

Wangiyana IGAS, Wanitaningsih SK, Sanjaya A. 2018. Bio-induksi Gyrinops versteegii Menggunakan Inokulan Berbahan Baku Medium Tauge dengan Berbagai Kedalaman Pengeboran. In: Prosiding Semniar Nasional Implementasi Iptek Pertanian Berkelanjutan yang Tangguh Menuju Kedaulatan Pangan. Mataram (ID): Universitas Mataram, 27 Januari 2018.

Wangiyana IGAS. 2015. Pemanfaatan Medium Alternatif untuk Pertumbuhan Isolat Fusarium Sp. Penginduksi Pembentukan Gaharu pada Gyrinops versteegii (Gilg) Domke. Jurnal Sangkareang Mataram. 1 (3): 54-59.

Yosephin MMAN, Adisasmuko S, Budi Utomo MM. 2012. Isolasi dan Karakterisasi Fungi Pembentuk Gaharu Hasil Eksplorasi yang Berasal dari Empat Lokasi di Nusa Tenggara Barat. Dalam: Seminar Nasional Hasil Hutan Bukan Kayu. Mataram (ID). 